\title{
Increasing Shallot Production in Marginal Land Using Mulches and Coconut Husk Fertilizer
}

\author{
Sri Anjar Lasmini*, Rosmini Rosmini, Irwan Lakani, Nur Hayati, Burhanuddin Haji Nasir \\ Faculty of Agriculture, Tadulako University, Palu, Central Sulawesi 94118, Indonesia
}

Corresponding Author Email: sri.anjar@untad.ac.id

https://doi.org/10.18280/ijdne.160114

Received: 10 December 2020

Accepted: 16 February 2021

\section{Keywords:}

Allium cepa L., cocopeat, dryland, mulch, organic fertilizer, rice straw

\begin{abstract}
The study aimed to obtain the type of mulch and the doses of liquid organic fertilizer proper waste coconut husks in modifying microclimate around crops to obtain the maximum yield of shallot in the dryland. The research was used a factorial randomized complete block design consisting of two factors. The first factor consisting mulches, M1 = silver-black plastic mulch and M2 = straw mulch. The dose of liquid organic fertilizer from coconut husks was the second factor. It is consisting of $\mathrm{S} 0=$ without fertilizer, $\mathrm{S} 1$ $=500 \mathrm{~L} \mathrm{ha}^{-1}, \mathrm{~S} 2=750 \mathrm{~L} \mathrm{ha}^{-1}$ and $\mathrm{S} 3=1000 \mathrm{~L} \mathrm{ha}^{-1}$. The results showed that the application of a combination of mulch and liquid organic fertilizer coconut husk waste significantly affected plant height, number of leaves per plant, number of tillers, and the bulb yield. Straw mulch with coconut husks waste dose of $1000 \mathrm{~L} \mathrm{ha}^{-1}$ resulted in plant height, number of leaves per plant, number of tillers and highest bulb yield compared with other treatments. The highest bulb yield was obtained with $9.63 \mathrm{t} \mathrm{ha}^{-1}$.
\end{abstract}

\section{INTRODUCTION}

Palu valley shallot (Allium cepa $\mathrm{L}$. var. aggregatum) is a raw material of fried shallots known to be very typical compared to other shallots in Indonesia. It grows well in various regions in Central Sulawesi, but its production from year-to-year decreases. Shallot production is steadily declining because, among other cultivation technology, it is not optimal as fertilization and irrigation, in this case, the nutrient needs and unmet water and climatic factors, mostly on dryland agro-ecosystem conditions. The element microclimate of the most influential in shallot cultivation in Central Sulawesi is the air temperature. To overcome extreme temperatures can be done by mulching, while the lack of nutrients needed by the plants can be done with a balanced fertilizer and organic matter.

Mulching is mostly used to cover the land to improve soil moisture, which can ultimately improve soil fertility and plant productivity $[1,2]$. The existence of mulch on the soil surface reduces soil temperature fluctuations between day and night, maintains soil moisture, and prevents weed growth [3]. Besides, the mulch will maintain a relative humidity of air at the surface continues to rise so that the evaporation speed can be limited [4]. Ram et al. [5] revealed that the mulch reduces soil temperature increases to minimize the evaporation, which causes groundwater levels not to decrease rapidly

Organic mulch is preferred, especially in organic farming systems. Organic mulch widely used is plant debris, straw, rice husk, sawdust, and other organic wastes. Several studies have reported that rice straw mulch can increase the yield on potato crops [6], soybeans [7], tomatoes [8], and maize [1]. The application of straw mulch will provide a good growth environment for plants because it can increase soil water content, reduce water evaporation and reduce soil temperature [5, 9], reduce soil carbon emissions [10], ensuring the availability of groundwater and nutrients [11], decreasing soil evaporation and increasing transpiration [4], and increasing soil microbial populations [6].

Organic farming develops organic fertilizer as compost, green manure, crop residues (straw, stover, corn cobs, sugarcane bagasse, and coconut husk), animal waste, and agricultural, industrial wastes applied to substitute chemical fertilizers. Coconut husks are planting materials that can absorb water in large quantities, improve aeration in agricultural land, and store water high [12]. Coconut husk contains cellulose, hemicellulose, lignin, and pectin [13]. It is also having potassium with low nitrogen and phosphorus [14]. When immersed in water, it will produce soaking water containing potassium, which is very good if given as a substitute for inorganic fertilizer [15].

Potassium is one of the macro fertilizers needed to enhance the growth and yield of shallot, but given $\mathrm{K}$ fertilizer rate still varies depending on soil type, season and way of planting, and shallot varieties used. The combination of $\mathrm{N}$ fertilizer dose of $150 \mathrm{~kg} \mathrm{ha}^{-1}$ and $\mathrm{K}$ fertilizer dose of $120 \mathrm{~kg} \mathrm{ha}^{-1}$ delivers growth and shallot yield, which is high compared with other doses [16]. Kamboj et al. [17] recommend using fertilizer K and $\mathrm{P}$ dose $125 \%$ of recommended doses to obtain growth and better results in the shallot crop. Furthermore, the use of organic fertilizers $5 \mathrm{t} \mathrm{ha}^{-1}+$ urea $100 \mathrm{~kg} \mathrm{ha}^{-1}+$ SP-36 $200 \mathrm{~kg} \mathrm{ha}^{-1}+$ NPK Phonska $300 \mathrm{~kg} \mathrm{ha}^{-1}$ gives higher bulb yield than without organic fertilizer on shallot [18], while Dapaah et al. [19] recommend $15 \mathrm{t} \mathrm{ha}^{-1}$ of poultry manure and $450 \mathrm{~kg} \mathrm{ha}^{-1} \mathrm{NPK}$ fertilizer for growing shallots, as well as the optimum dose of $\mathrm{K}$ fertilizer on sorghum crop was obtained at $90 \mathrm{~kg} \mathrm{ha}^{-1}$ [20], and $300 \mathrm{~kg} \mathrm{ha}^{-1}$ in shallots [21].

The use of coconut husk as a liquid organic fertilizer that contains potassium macroelements is an alternative technology that can be considered to substitute the use of inorganic fertilizers, especially potassium fertilizer [15]. The 
potential of coconut husk in Indonesia is very large considering that the country is known as the largest coconut producer in the Asian region. If coconut husk is used, it will reduce environmental pollution and increase the economic value of coconut husk waste. Here, the mulch and liquid organic fertilizer's effectiveness from coconut husk was determined to improve the growth and yield of shallot on marginal land.

\section{MATERIALS AND METHODS}

\subsection{Study site and meteorological condition}

The study was conducted from January 2017 to November 2017 in the Bulupountu Jaya village, Central Sulawesi, Indonesia $\left(119^{\circ} 57^{\prime} 10^{\prime \prime} \mathrm{E}, 1^{\circ} 1^{\prime} 51^{\prime \prime} \mathrm{E}\right)$ with an altitude of $120 \mathrm{~m}$ above sea level. The soil is classified as Inceptisol.

\subsection{Experimental design}

A factorial randomized complete block design was applied in this study. Two factors were assessed. The first factor is the type of mulch that consists of two levels: M1= silver-black plastic mulch, and M2= rice straw mulch. The dose of liquid fertilizer, as the second factor, consisting of four levels: $\mathrm{S} 0=$ without fertilizer, $\mathrm{S} 1=$ dose of $500 \mathrm{~L} \mathrm{ha}^{-1}, \mathrm{~S} 2=$ dose of $750 \mathrm{~L}$ $\mathrm{ha}^{-1}$, and S3 $=$ dose of $1000 \mathrm{~L} \mathrm{ha}^{-1}$. Of the two factors obtained, eight combined treatment with three replications, so that there are 24 experimental units.

Before planting shallots, first conducted experiments raised beds measuring $2 \times 4$ meters. Two weeks before planting, cow manure was given as much as $5 \mathrm{t} \mathrm{ha}^{-1}$ as a basic fertilizer. Silver-black plastic mulch was installed one week before planting, and liquid manure waste coconut husks were given one week after planting with appropriate treatment doses.

Shallots are planted in experimental plots measuring $2 \times 4$ $\mathrm{m}$ with a $15 \times 20 \mathrm{~cm}$ spacing, so there are 360 plants in each plot. Plant maintenance was applied, such as watering, weeding, and pest and disease control adapted to the condition of crops in the field.

\subsection{Observation and data analysis}

The parameters observed were the growth and yield components, which were consisted of: (i) plant height, (ii) number of leaves per plant, (iii) number of tillers, and (iv) yield production of shallot. Plant height and number of leaves were observed at the age of 2 to 7 weeks after planting (WAP), the number of tillers was observed at the age of 5 to 7 WAP, and production of bulb yield was observed at harvest. Plant height was measured by the meter from ground level up to the highest growing point. The number of leaves per plant was counted by the number of leaves in each clump of the plant.
The number of the tillers was calculated by the number of tillers per clump of a plant. The shallot bulbs yield was observed at harvest by measuring the weight of fresh bulbs per plot sample and then converted to a hectare.

Data of growth and yield observations were collected and analyzed by $F$ test. If the test of analysis of variance (ANOVA) differs significantly, by honestly significant difference (HSD) test with $95 \%$ confidence interval.

\section{RESULTS}

\subsection{Effect of mulch and liquid organic fertilizer on shallot growth}

A significant effect of the combination of mulch with the dosage of coconut husk liquid organic fertilizer on plant height, number of leaves per plant, and number of tillers per clump was recorded in this study. In contrast, there was no interaction between mulch and coconut husk liquid organic fertilizer.

The highest plant was $32.26 \mathrm{~cm}$, the highest number of leaves was 27.03 strands, and the highest number of tillers was 6.37 obtained in the combination treatment of rice straw mulch with a dose of organic fertilizer from coconut husk liquid waste $1000 \mathrm{~L} \mathrm{ha}^{-1}$. That treatment result was significantly different from others except for the number of tillers, which was not significantly different from the combination of silverblack plastic mulch treatment and the dose of liquid organic fertilizer from coconut husk waste of $1000 \mathrm{~L} \mathrm{ha}^{-1}$ (Table 1).

The straw mulch contributed to the highest plant height of $25.23 \mathrm{~cm}$ (Table 2), the highest number of leaves per plant was 22.43 (Table 3), and the highest number of tillers was 5.45 tiller (Table 4) compared to black-silver plastic mulch. In the treatment of liquid organic fertilizer at a dose of $1000 \mathrm{~L} \mathrm{ha}^{-1}$ (S3), the highest plant height was $27.92 \mathrm{~cm}$ (Table 2), the highest number of leaves per plant was 22.92 (Table 3), and the highest number of tillers was 6.07 tiller (Table 4) compared with other treatment doses.

Table 1. Effect of combination of mulches and liquid organic fertilizer doses on shallot growth

\begin{tabular}{cccc}
\hline Treatment & $\begin{array}{c}\text { Plant } \\
\text { height } \\
\text { (cm) }\end{array}$ & $\begin{array}{c}\text { Number of } \\
\text { leaves } \\
\text { (strands) }\end{array}$ & $\begin{array}{c}\text { Number of } \\
\text { tillers } \\
\text { (tiller) }\end{array}$ \\
\hline M1S0 & $16.22 \mathrm{a}$ & $13.30 \mathrm{a}$ & $4.17 \mathrm{a}$ \\
M2S0 & $21.70 \mathrm{bc}$ & $18.70 \mathrm{c}$ & $4.73 \mathrm{ab}$ \\
M1S1 & $18.05 \mathrm{ab}$ & $14.20 \mathrm{ab}$ & $4.77 \mathrm{abc}$ \\
M2S1 & $22.57 \mathrm{c}$ & $20.87 \mathrm{~cd}$ & $5.13 \mathrm{bcd}$ \\
M1S2 & $21.01 \mathrm{bc}$ & $17.17 \mathrm{bc}$ & $4.93 \mathrm{abc}$ \\
M2S2 & $24.51 \mathrm{c}$ & $23.10 \mathrm{~d}$ & $5.57 \mathrm{cde}$ \\
M1S3 & $23.76 \mathrm{c}$ & $18.80 \mathrm{c}$ & $5.77 \mathrm{de}$ \\
M2S3 & $32.26 \mathrm{~d}$ & $27.03 \mathrm{e}$ & $6.37 \mathrm{e}$ \\
\hline HSD 0.05 & 4.33 & 3.95 & 0.80 \\
\hline Notes: The numbers followed by the same letter in the same column are not
\end{tabular}

Notes: The numbers followed by the same letter in the same column are not significantly different at test HSD 5\%.

Table 2. Effect of mulches and liquid organic fertilizer doses at aged of 2-7 weeks after planting (WAP) on shallot height (cm)

\begin{tabular}{ccccccc}
\hline Treatment & 2 WAP & 3 WAP & 4 WAP & 5 WAP & 6 WAP & 7 WAP \\
\hline M1 & $10.86 \mathrm{a}$ & $13.10 \mathrm{a}$ & $14.99 \mathrm{a}$ & $17.80 \mathrm{a}$ & $19.47 \mathrm{a}$ & $19.73 \mathrm{a}$ \\
M2 & $11.48 \mathrm{~b}$ & $15.05 \mathrm{~b}$ & $17.19 \mathrm{~b}$ & $20.18 \mathrm{~b}$ & $23.30 \mathrm{~b}$ & $25.23 \mathrm{~b}$ \\
\hline HSD 0.05 & 0.38 & 0.72 & 1.26 & 1.37 & 1.49 & 4.39 \\
\hline S0 & $9.62 \mathrm{a}$ & $12.55 \mathrm{a}$ & $14.38 \mathrm{a}$ & $15.73 \mathrm{a}$ & $18.50 \mathrm{a}$ & $18.87 \mathrm{a}$ \\
S1 & $11.15 \mathrm{~b}$ & $13.75 \mathrm{~b}$ & $15.37 \mathrm{ab}$ & $17.80 \mathrm{~b}$ & $20.27 \mathrm{ab}$ & $20.40 \mathrm{ab}$ \\
S2 & $11.50 \mathrm{~b}$ & $14.40 \mathrm{bc}$ & $16.35 \mathrm{~b}$ & $19.72 \mathrm{bc}$ & $22.13 \mathrm{~b}$ & $22.73 \mathrm{ab}$ \\
S3 & $12.40 \mathrm{c}$ & $15.60 \mathrm{c}$ & $18.27 \mathrm{c}$ & $22.72 \mathrm{c}$ & $24.63 \mathrm{c}$ & $27.92 \mathrm{~b}$ \\
\hline HSD 0.05 & 0.54 & 1.02 & 1.78 & 1.94 & 2.10 & 6.22 \\
\hline
\end{tabular}

Notes: The numbers followed by the same letter in the same column are not significantly different at test HSD $5 \%$. 
Table 3. Effect of mulches and liquid organic fertilizer doses at aged of 2-7 weeks after planting (WAP) on number of leaves per plant (strands)

\begin{tabular}{ccccccc}
\hline Treatment & 2 WAP & 3 WAP & 4 WAP & 5 WAP & 6 WAP & 7 WAP \\
\hline M1 & $9.43 \mathrm{a}$ & $11.53 \mathrm{a}$ & $12.69 \mathrm{a}$ & $13.25 \mathrm{a}$ & $15.64 \mathrm{a}$ & $15.87 \mathrm{a}$ \\
M2 & $11.28 \mathrm{~b}$ & $13.09 \mathrm{~b}$ & $16.42 \mathrm{~b}$ & $18.03 \mathrm{~b}$ & $22.37 \mathrm{~b}$ & $22.43 \mathrm{~b}$ \\
\hline HSD 0.05 & 0.38 & 0.72 & 1.26 & 1.37 & 1.49 & 4.39 \\
\hline S0 & $9.45 \mathrm{a}$ & $10.32 \mathrm{a}$ & $12.12 \mathrm{a}$ & $13.43 \mathrm{a}$ & $15.70 \mathrm{a}$ & $16.00 \mathrm{a}$ \\
S1 & $10.12 \mathrm{~b}$ & $11.88 \mathrm{~b}$ & $13.98 \mathrm{~b}$ & $14.98 \mathrm{ab}$ & $17.45 \mathrm{ab}$ & $17.53 \mathrm{ab}$ \\
S2 & $10.68 \mathrm{~b}$ & $13.07 \mathrm{c}$ & $14.92 \mathrm{bc}$ & $15.73 \mathrm{~b}$ & $20.13 \mathrm{~b}$ & $20.13 \mathrm{~b}$ \\
S3 & $11.17 \mathrm{c}$ & $13.98 \mathrm{c}$ & $17.20 \mathrm{c}$ & $18.40 \mathrm{c}$ & $22.73 \mathrm{~b}$ & $22.92 \mathrm{c}$ \\
\hline HSD 0.05 & 0.61 & 1.23 & 1.69 & 1.94 & 2.81 & 2.79 \\
\hline
\end{tabular}

Notes: The numbers followed by the same letter in the same column are not significantly different at test HSD $5 \%$.

Table 4. Effect of mulches and liquid organic fertilizer doses at aged of 5-7 weeks after planting (WAP) on number of tillers (tiller)

\begin{tabular}{cccc}
\hline Treatment & 5 WAP & 6 WAP & 7 WAP \\
\hline M1 & $3.79 \mathrm{a}$ & $4.53 \mathrm{a}$ & $4.91 \mathrm{a}$ \\
M2 & $4.48 \mathrm{~b}$ & $5.18 \mathrm{~b}$ & $5.45 \mathrm{~b}$ \\
\hline HSD 0.05 & 0.23 & 0.36 & 0.40 \\
\hline S0 & $3.45 \mathrm{a}$ & $4.15 \mathrm{a}$ & $4.45 \mathrm{a}$ \\
S1 & $4.10 \mathrm{~b}$ & $4.58 \mathrm{ab}$ & $4.95 \mathrm{ab}$ \\
S2 & $4.35 \mathrm{~b}$ & $4.98 \mathrm{~b}$ & $5.25 \mathrm{~b}$ \\
S3 & $4.65 \mathrm{bc}$ & $5.72 \mathrm{c}$ & $6.07 \mathrm{c}$ \\
\hline HSD 0.05 & 0.33 & 0.51 & 0.57 \\
\hline
\end{tabular}

Notes: The numbers followed by the same letter in the same column are not significantly different at test HSD 5\%.

\subsection{Effect of mulch and liquid organic fertilizer on shallot yield}

The yield of bulbs significantly affected the combination of mulch types with liquid organic fertilizer from coconut husk waste. The combined application of straw mulch with a liquid organic fertilizer at a dose of $1000 \mathrm{~L} \mathrm{ha}^{-1}$ resulted in the highest shallot bulb weight, namely $9.63 \mathrm{t} \mathrm{ha}^{-1}$ (Table 5).

Table 5. Effect of combined mulches and liquid organic fertilizer doses on shallot bulb yield $\left(\mathrm{t} \mathrm{ha}^{-1}\right)$

\begin{tabular}{cc}
\hline Treatment & Bulb yield $\left(\mathbf{t ~ h a}^{-\mathbf{1}}\right)$ \\
\hline M1S0 & $4.27 \mathrm{a}$ \\
M2S0 & $4.83 \mathrm{ab}$ \\
M1S1 & $5.17 \mathrm{bc}$ \\
M2S1 & $6.93 \mathrm{~d}$ \\
M1S2 & $5.83 \mathrm{c}$ \\
M2S2 & $8.10 \mathrm{e}$ \\
M1S3 & $7.63 \mathrm{de}$ \\
M2S3 & $9.63 \mathrm{f}$ \\
\hline HSD 0.05 & 0.76 \\
\hline
\end{tabular}

Notes: The numbers followed by the same letter in the same column are not significantly different at test HSD 5\%.

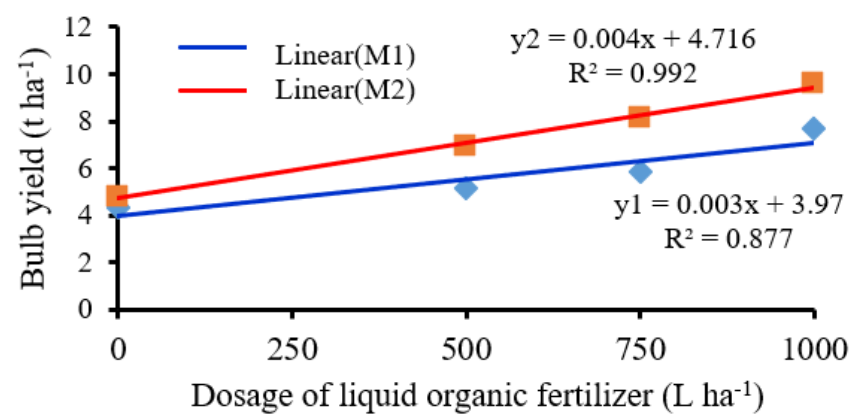

Figure 1. The relationship between the dose of liquid organic fertilizer coconut husk waste and the yield of shallot bulbs
Further analysis with regression on each mulch application shows that black-silver plastic mulch (M1) responded to variations in the dosage of coconut husk liquid organic fertilizer in the form of a linear function, namely $\mathrm{y} 1=0.003 \mathrm{x}$ +3.97 with $\mathrm{R}^{2}=0.877$ and rice straw mulch (M2) with the linear function, namely $\mathrm{y} 2=0.004 \mathrm{x}+4.716$ with $\mathrm{R}^{2}=0.992$ ( $y 1$ is the yield of bulb $t$ ha $^{-1}$ in silver-black plastic mulch application, and $\mathrm{y} 2$ is the yield of blub $\mathrm{t} \mathrm{ha}^{-1}$ in straw mulch application; $\mathrm{x}$ is the dose of liquid organic fertilizer) (Figure 1). The regression analysis showed that the use of liquid organic fertilizer from coconut husk waste at a dose of $1000 \mathrm{~L}$ $\mathrm{ha}^{-1}$ gave the best response to the yield of shallot bulbs.

\section{DISCUSSION}

\subsection{Effect of mulch and liquid organic fertilizer on shallot growth}

One way to increase shallot production is to improve cultivation techniques with fertilization and mulch. Fertilization can use organic and inorganic fertilizers. To overcome dependence on the use of inorganic fertilizers is to provide organic fertilizers. Straw mulch produces more bulbs and more plant leaves than silver-black plastic mulch. Straw mulch can reduce evaporation so that moisture around the plant is maintained, which causes shallot plants to use water to support their growth. Kader et al. [22] suggested that one way to reduce water evaporation in the soil to make it more efficient is to use mulch. Furthermore, several studies have shown that organic fertilizer and rice straw can increase the growth and yields of shallots [23, 24].

Liquid organic coconut husk fertilizer at $1000 \mathrm{~L}$ dose ha ${ }^{-1}$ showed an increase in plant height and plant leaves. A possible explanation for this might be that potassium contained in coconut coir waste plays a direct role in forming amino acids, proteins, nucleic acids, enzymes, nucleoproteins, and alkaloids needed for plant growth, especially leaf development, adding to the green color as well as branch formation [25, 26]. Lack of $\mathrm{N}$ and $\mathrm{K}$ can limit cell division and enlargement so that the addition of $\mathrm{N}$ and $\mathrm{K}$ fertilizers is sufficient to stimulate optimal plant growth [27].

Bassiony [28] suggested that shallot growth increases gradually with an increasing amount of $\mathrm{K}$ fertilizer. $\mathrm{K}$ fertilizer can increase the vegetative growth of shallot plants. The application of $\mathrm{K}$ fertilizer in the soil is sufficient to make the growth of shallots more optimally [29]. The addition of high doses of potassium shows good results because potassium plays an essential role in helping the photosynthesis process, forming new organic compounds transported from storage organs to the bulb. Another effect of potassium fertilization is that it helps produce high-quality bulbs $[21,30]$. 


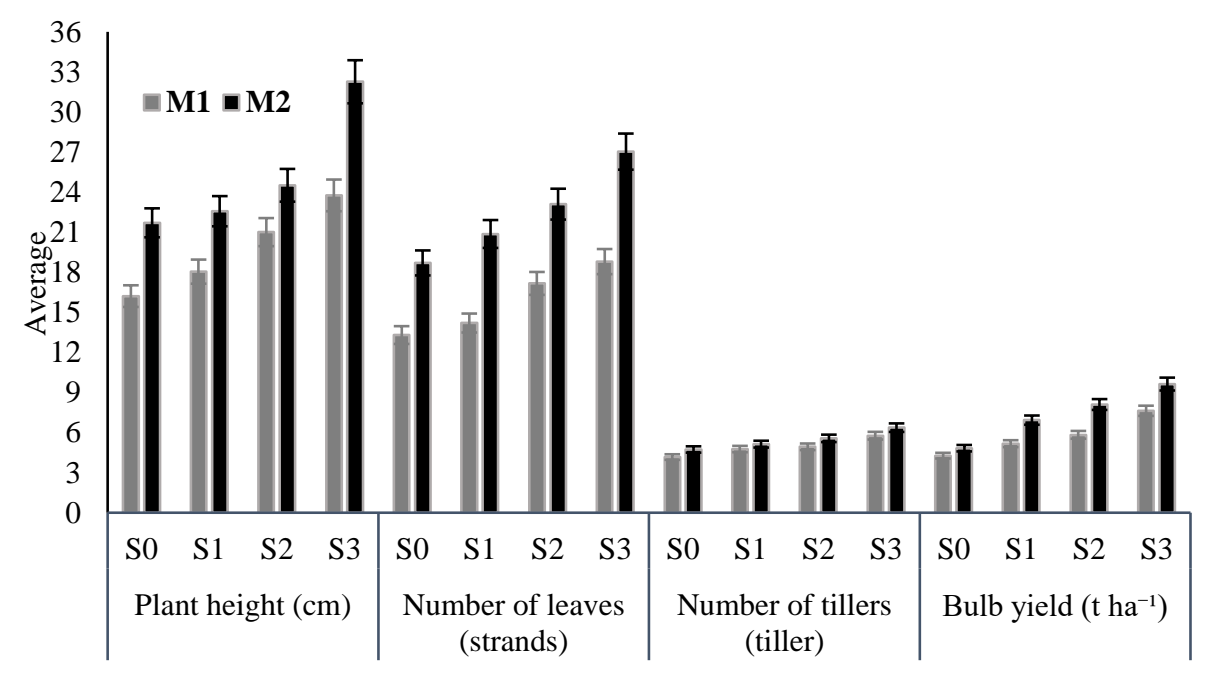

Figure 2. Effect of mulches and liquid organic fertilizer doses on shallot growth and yield

The mulch of rice straw and liquid coconut husk waste up to a dose of $1000 \mathrm{~L} \mathrm{ha}^{-1}$ increased plant height, number of leaves per plant, and number of tillers (Figure 2) when compared to other treatments. Plant growth has a positive correlation with increasing the dose of potassium fertilizer. Potassium plays a vital role as an activator of several enzymes in plant metabolism, such as potassium plays a role in protein and carbohydrate synthesis and increases the transport of photosynthate translocation to all parts of the plant [31]. Potassium is also important for maintaining cell turgor pressure and plant moisture content, and drought and increasing crop yield and quality $[16,32,33]$.

\subsection{Effect of mulch and liquid organic fertilizer on shallot yield}

The availability of potassium in the rare earth is sufficient to support essential processes such as sugar transport from leaf to the bulb, enzyme activity, protein synthesis, and cell enlargement, ultimately determining yield and quality. The absorption of potassium by plants is influenced by soil texture, soil moisture and temperature, and soil $\mathrm{pH}$ and aeration [34].

Potassium status has a significant effect on the yield of shallot plants. The higher the potassium, the higher the yield of shallot plants produced (Figure 2). This occurs because the provision of sufficient potassium in the soil is crucial to increase shallot plants' growth [16, 33]. The function of potassium is directly involved in regulating the biochemical and physiological processes of plant growth. Potassium can also render plants less technical, more resistant to disease, and environmental stress $[35,36]$. The higher the soil potassium status, the higher the yield ball. Low bulb yields obtained on soils with low potassium status are caused by nutrient deficiency plants, which play an important role in translocation and assimilation storage, increase in bulb size, number, and yield per plant $[37,38]$. The need for potassium increases before harvest as it functions for photosynthesis [33, 39], and shallot plants take up potassium in the same amount as nitrogen [40-43].

\section{CONCLUSIONS}

The present study was designed to determine the effect of mulches and liquid organic fertilizer to increase shallot production under dryland conditions. These experiments confirmed a linear relationship between the combination of mulch and the liquid organic fertilizer dose to the yield of shallot bulbs (Allium cepa L. var. aggregatum). The higher the dose given, the higher the results obtained. The combination of mulch and liquid organic fertilizer from coconut husk waste significantly affected plant height, number of leaves per plant, number of tillers, and bulb yield. Straw mulch with coconut husk waste at a dose of $1000 \mathrm{~L} \mathrm{ha}^{-1}$ produced the highest plant height, number of leaves per plant, number of tillers, and yield of shallot bulb compared to other treatments. The highest bulb yield was $9.63 \mathrm{t} \mathrm{ha}^{-1}$. This study's findings suggest that the cultivation of shallots in dryland needs to apply a liquid organic fertilizer to substitute inorganic fertilizers and increase the quality and quantity of shallots.

\section{ACKNOWLEDGMENT}

This article is a part of an applied research study funded by the Directorate for Research and Community Services, Directorate-General for Strengthening Research and Development of the Ministry of Research, Technology and Higher Education of the Republik of Indonesia, following contract No. 106/SP2H/LT/DRPM/IV/2017.

\section{REFERENCES}

[1] Zamir, M.S.I., Javeed, H.M.R., Ahmed, W., Ahmed, A.U.H., Sarwar, N., Shehzad, M., Sarwar, M.A., Iqbal, S. (2013). Effect of tillage and organic mulches on growth, yield and quality of autumn planted maize (Zea mays L.) and soil physical properties. Cercetări Agronomice în Moldova, 46(2): 17-26. https://doi.org/10.2478/v10298012-0080-Z

[2] Zhao, Y.G., Pang, H.C, Wang, J., Huo, L., Li, Y.Y. (2014). Effects of straw mulch and buried straw on soil moisture and salinity in relation to sunflower growth and yield. Field Crops Research, 161: 16-25. https://doi.org/10.1016/j.fcr.2014.02.006

[3] DeVetter, L.W., Dilley, C.A., Nonnecke, G.R. (2015). Mulches reduce weeds, maintain yield, and promote soil quality in a continental-climate vineyard. American 
Journal of Enology and Viticulture, 66: 54-64. https://doi.org/10.5344/ajev.2014.14064

[4] Balwinder-Singh, Eberbach, P.L., Humphreys, E., Kukal, S.S. (2011). The effect of rice straw mulch on evapotranspiration, transpiration and soil evaporation of irrigated wheat in Punjab, India. Agricultural Water Management, 98(12): 1847-1855. https://doi.org/10.1016/j.agwat.2011.07.002

[5] Ram, H., Dadhwal, V., Vashist, K.K., Kaur, H. (2013). Grain yield and water use efficiency of wheat (Triticum aestivum L.) in relation to irrigation levels and rice straw mulching in North West India. Agricultural Water Management, 128:

92-101.

https://doi.org/10.1016/j.agwat.2013.06.011

[6] Bhagat, P., Gosal, S.K., Singh, C.B. (2016). Effect of mulching on soil environment, microbial flora and growth of potato under field conditions. Indian Journal of Agricultural Research, 50: 542-548. https://doi.org/10.18805/ijare.v50i6.6671

[7] Akhtar, K., Wang, W., Ren, G., Khan, A., Feng, Y., Yang, G., Wang, H. (2019). Integrated use of straw mulch with nitrogen fertilizer improves soil functionality and soybean production. Environment International, 132: 105092. https://doi.org/10.1016/j.envint.2019.105092

[8] Kosterna, E. (2014). The effect of soil mulching with straw on the yield and selected components of nutritive value in broccoli and tomatoes. Folia Horticulturae, 26(1): 31-42. https://doi.org/10.2478/fhort-2014-0003

[9] Bunna, S., Sinatha, P., Makaraa, O., Mitchell, J., Fukai, S. (2011). Effects of straw mulch on mungbean yield in rice fields with strongly compacted soils. Field Crops Research, 124(3): 295-301. https://doi.org/10.1016/j.fcr.2011.06.015

[10] Dossou-Yovo, E.R., Brüggemann, N., Jesse, N., Huat, J., Ago, E.E., Agbossou, E.K. (2016). Reducing soil $\mathrm{CO}_{2}$ emission and improving upland rice yield with no-tillage, straw mulch and nitrogen fertilization in northern Benin. Soil and Tillage Research, 156: 44-53. https://doi.org/10.1016/j.still.2015.10.001

[11] Stagnari, F., Galieni, A., Speca, S., Cafiero, G., Pisante, M. (2014). Effects of straw mulch on growth and yield of durum wheat during transition to conservation agriculture in Mediterranean environment. Field Crops Research, 167: 51-63. https://doi.org/10.1016/j.fcr.2014.07.008

[12] Udayana, S.K., Naorem, A., Singh, N.A. (2017). The multipurpose utilization of coconut by-products in agriculture: Prospects and concerns. International Journal of Current Microbiology and Applied Sciences, 6(6):

$1408-1415$

https://doi.org/10.20546/IJCMAS.2017.606.165

[13] Mittal, M., Chaudhary, R. (2018). Experimental study on the water absorption and surface characteristics of alkali treated pineapple leaf fibre and coconut husk fibre. International Journal of Applied Engineering Research, 13(15): 12237-12243.

[14] Kumar, S., Ganesh, R. (2012). Effect of different biocomposting techniques on physico-chemical and biological changes in coir pith. International Journal of Recent Scientific Research, 3(11): 914-918.

[15] Evans, M.R., Konduru, S., Stamps, R.H. (1996). Source variation in physical and chemical properties of coconut coir dust. HortScience, 31(6): 965-967. https://doi.org/10.21273/HORTSCI.31.6.965
[16] Ali, M.K., Alam, M.F., Alam, M.N., Islam, M.S., Khandaker, S.M.A.T. (2007). Effect of nitrogen and potassium level on yield and quality seed production of onion. Journal of Applied Sciences Research, 3(12): 1889-1899.

[17] Kamboj, N.K., Batra, V.K., Brar, N.S., Rana, M.K. (2017). Effect of various plant density at different levels of phosphorous and potash on growth and seed yield of onion (Allium cepa L.) cv. Hisar-2. Indian Journal of Agricultural Research, 51(5): 514-517. https://doi.org/10.18805/IJARe.A-4749

[18] Purba, R. (2016). Study of the use of organic fertilizer on onion farming system in Serang, Banten. Planta Tropical Journal of Agro Science, 4: 1-6. https://doi.org/10.18196/pt.2016.049.1-6

[19] Dapaah, H.K., Amoh-Koranteng, J.G., Darkwah, K., Borketey-La, E.B. (2014). Influence of poultry manure and NPK fertilization on growth, yield, and storability of onion (Allium cepa L.) grown under rain-fed conditions. American Journal of Experimental Agriculture, 4(8): 866-878. https://doi.org/10.9734/AJEA/2014/7526

[20] Suminar, R., Suwarto, Purnamawati, H. (2017). The determination of the optimum dosage of fertilizer $\mathrm{N}, \mathrm{P}$, and $\mathrm{K}$ in sorghum (Sorghum bicolor [L.] Moench). Indonesian Journal of Agricultural Sciences, 22(1): 6-12. https://doi.org/10.18343/jipi.22.1.6

[21] Behairy, A.G., Mahmoud, A.R., Shafeek, M.R., Ali, A.H., Hafez, M.M. (2015). Growth, yield and bulb quality of onion plants (Allium cepa L.) as affected by foliar and soil application of potassium. Middle East Journal of Agriculture Research, 4(1): 60-66.

[22] Kader, M.A., Senge, M., Mojid, M.A., Ito, K. (2017). Recent advances in mulching materials and methods for modifying soil environment. Soil and Tillage Research, 168: 155-166. https://doi.org/10.1016/j.still.2017.01.001

[23] Lasmini, S.A., Wahyudi, I., Rosmini, R., Nasir, B., Edy, N. (2019). Combined application of mulches and organic fertilizers enhance shallot production in dryland. Agronomy Research, 17(1): 165-174. http://dx.doi.org/10.15159/ar.19.017

[24] Rachel, M., Mondal, M., Pramanik, M., Awal, M. (2018). Mulches enhanced growth and yield of onion. Bangladesh Journal of Scientific and Industrial Research, 53(4):

305-310. https://doi.org/10.3329/bjsir.v53i4.39195

[25] Nasreen, S., Haque, M.M., Hossain, M.A., Farid, A.T.M. (2007). Nutrient uptake and yield of onion as influenced by nitrogen and sulfur fertilization. Bangladesh Journal of Agricultural and Research, 32(3): 413-420. https://doi.org/10.3329/bjar.v32i3.543

[26] Abdissa, Y., Tekalign, T., Pant, L.M. (2011). Growth, bulb yield and quality of onion (Allium cepa L.) as influenced by nitrogen and phosphorus fertilization on Vertisol. African Journal of Agricultural Research, 6(14): 3252-3258. https://doi.org/10.5897/AJAR10.1024

[27] Li, Z., Zhang, R., Xia, S., Wang, L., Liu, C., Zhang, R., Fan, Z., Chen, F., Liu, Y. (2019). Interactions between N, $\mathrm{P}$ and $\mathrm{K}$ fertilizers affect the environment and the yield and quality of satsumas. Global Ecology and Conservation, 19 : e00663. https://doi.org/10.1016/j.gecco.2019.e00663

[28] Behairy, A.G., Mahmoud, A.R., Shafeek, M.R., Ali, A.H., Hafez, M.M. (2015). Growth, yield and bulb quality of onion plants (Allium cepa L.) as affected by 
foliar and soil application of potassium. Middle East Journal of Agriculture Research, 4(1): 60-66.

[29] Abdulrachman, S., Susanti, Z. (2004). Effect of zeolite on efficiency of $\mathrm{P}$ and $\mathrm{K}$ fertilizers in the paddy field. Journal of Indonesian Zeolites, 3(1): 1-14.

[30] Li, P., Tian, Q., Peng, Z., Fang, Z., Qing, Y., Zhao, H. (2020). Main agronomic traits and photosynthetic pathways of potatoes. International Journal of Design \& Nature and Ecodynamics, 15(3): 431-439. https://doi.org/10.18280/ijdne.150317

[31] Jaiswal, D.K., Verma, J.P., Prakash, S., Meena, V.S., Meena, R.S. (2016). Potassium as an important plant nutrient in sustainable agriculture: A state of the art. In V.S. Meena et al., ed. Potassium Solubilizing Microorganisms for Sustainable Agriculture. Springer, New Delhi, 21-29. https://doi.org/10.1007/978-81-3222776-2

[32] Zörb, C., Senbayram, M., Peiter, E. (2014). Potassium in agriculture - Status and perspectives. Journal of Plant Physiology, 171(9): 656-669. https://doi.org/10.1016/j.jplph.2013.08.008

[33] Mozumder, S.N., Moniruzzaman, M., Halim, G.M.A. (2007). Effect of N, K, and S on the yield and storability of transplanted onion (Allium cepa L.) in Hilly region. Journal of Agriculture \& Rural Development, 5(1): 5863. https://doi.org/10.3329/jard.v5i1.1459

[34] Aftab, S., Hamid, F., Farrukh, S., Waheed, A., Ahmed, N., Khan, N., Ali, S., Bashir, M., Mumtaz, S., Gul, H., Younis, M. (2017). Impact of potassium on the growth and yield contributing attributes of onion (Allium cepa L.). Asian Research Journal of Agriculture, 7(3): 1-4. https://doi.org/10.9734/ARJA/2017/38322

[35] Razzaque, A.H.M., Ali, M.I., Habibullah, A.K.M. (1990). Response of boror rice to potassium application in two soil of Bangladesh. Journal of Soil Science, 21(1): 26-29.

[36] Zörb, C., Senbayram, M., Peiter, E. (2014). Potassium in agriculture - Status and perspectives. Journal of Plant Physiology, 171(9): 656-669. https://doi.org/10.1016/j.jplph.2013.08.008

[37] Barman, H.K., Siddiqui, M.N., Siddique, M.A., Roni, M.S., Nuruzzaman, M. (2013). Combined effect of organic manure and potassium on growth and yield of onion cv. Bari Piaz-1. International Journal of Agricultural Research Innovation and Technology, 3(1): 47-51. http://dx.doi.org/10.3329/ijarit.v3i1.16092

[38] Garg, R., Singh, S.S., Jadia, M., Bairwa, J., Tiwari, V.K., Yadav, R.S. (2018). Interaction effect of sulphur and potash on growth, bulb yield and nutritional values of onion (Allium cepa L.). Journal of Pharmacognosy and Phytochemistry, 7(2): 746-748.

[39] Greenwood, D.J., Stone, D.A. (1998). Prediction and measurement of the decline in the critical-K, the maximum-K and total cation concentration plant during the growth of field vegetable crops. Annals of Botany, 82(6): 871-881. https://doi.org/10.1006/anbo.1998.0775

[40] Pire, R., Ramized, H., Riera, J., Gomez de, T.N. (2001). Removal of N, P, K and Ca by an onion (Allium cepa L.) in silty clay soil, in the semi-arid region of Venezuela. Acta Horticulturae, 555: 103-109. https://doi.org/10.17660/ActaHortic.2001.555.12

[41] Salo, T., Suojala, T., Kallela, M. (2002). The effect of fertigation on yield and nutrient uptake of cabbage, carrot, and onion. Acta Horticulturae, 571: 235-241. https://doi.org/10.17660/ActaHortic.2002.571.28

[42] Singh, S.P., Verma, A.B. (2001). Response of onion (Allium cepa L.) to potassium application. Indian Journal of Agronomy, 46(1): 182-185. http://dx.doi.org/10.18782/2320-7051.6394

[43] Kumara, B.R., Mansur, C.P., Wani, S.P., Chander, G., Allolli, T.B., Jagadeesh, S.L., Mesta, R.K., Meti, S., Satish, D., Reddy, S.G. (2018). Response of onion (Allium cepa L.) to potassium levels, sources and time of application. International Journal of Pure \& Applied Bioscience, 6(2): http://dx.doi.org/10.18782/2320-7051.6394 